\title{
The Essential Oils of Mentha rotundifolia of European Origin
}

\section{(Studies on the Essential Oil of Mentha rotundifolia, Part IV)}

Sir :

Rotundifolone $\mathrm{C}_{10} \mathrm{H}_{14} \mathrm{O}_{2}$, the principal component of Mentha rotundifolia oil in Japan, has been established to be 1-methyl-4-isopropylidene-1, 2-epoxy-cyclohexanone-3 (1, 2-epoxypiperitenone) by our previous reports.1) Reitsema ${ }^{2)}$ isolated the same ketone from the oil of American $M$. rotundifolia and independently gave the same structure as ours via a different way. However, Rovesti,3) Schimmel group ${ }^{4)}$ and Costa5) did not find any $\alpha, \beta$ unsaturated ketone in their European rotundifolia oils. On the other hand, pulegone was found in the oils of Argentina ${ }^{\circ}$ and Morocco.7) Our Japanese $M$. rotundifolia, though is not native in this country, was introduced as a sample from an unknown foreign country about twenty years ago. According to Murray, ${ }^{8)}$ the American strain is shown to be of European origin.

From the above-mentioned facts, $M$. rotundifolia will presumablly be native in Europe and may at least be divided into two groups; one contains rotundifolone, and the other does not. In order to elucidate this problem, we have collected various strains of $M$. rotundifolia of European origin, which are shown in the following Table I:

Since the genus Mentha is taxonomically exceedingly complicated, the seeds of European origin mentioned above were imported and cultivated in Okayama, Japan. The somatic chromosome numbers of each strain were determined to be 24 by the method re-

\footnotetext{
1) S. Shimizu, Journal of the Faculty of Agric., Sbinsyz Univ., 1) S. Shimizu, Journal of the Faculty of Agric.
No. 6, 1-39 (1956); This Bulletin, 21, 107 (1957)

2) 6. 1-39 (1956); This Bulletin, 21, 107 (1957).

2) R. H. Reitsema, J. Am. Cbem. Soc, 78, $\mathrm{7}$.

3) R. Rovesti, Prof umi italici, 3, 178

5) Ber. Scbimmel Co., April 80 (1907). 6) G. A. Fester, E. A. Martinuzzi, J. A. Retamer and I. A Ricciardi, Biol. de la Academia National de Ciencias, 39, $386(1956)$ C. A., 7658 (1957).

7) J. Gattefosse and G. Igolen, Ber. Schimmel Co, 70 (1950) C. A., $7193 .(1949)$,

8) Private communication from Dr. V.J. Varnis, A. M. Todd Co., Oct. 10, 1957.
}

TABLE I

1. France: Jardin Botanique de Toulouse, 1955.

2. Jugoslavija: Hortus Botanicus Univ. Ljubljana, 1955 .

3. Bergie: Plantentuin der Rijiksuniversiteit te Gent, 1955.

4. Italy: Instituto ed Ort Botanico della Univ. di Roma, 1955.

5. Polgne: Institut Scientique National des Drougues végètales, Poznan, 1956.

6. Portugal : Estaçaỗ Agronomica Nacional Sacavém, 1956.

ported previously.9) The essential oils of these strains were found to have the following physico-chemical properties;

TABLE II

$\begin{array}{llllcc}\text { Origin } & \lambda_{\max } & \begin{array}{c}\text { Optical density } \\ (10 \gamma / \mathrm{cc})\end{array} & d_{4}^{20} & n_{\mathbf{D}}^{20} & {[\alpha]_{\mathbf{D}}^{20}} \\ \text { France } & 235 \mathrm{~m} \mu & 0.240 & 0.934 & 1.4833 & -3.27^{\circ} \\ \text { Jugoslavia } & 260 & 0.481 & 1.024 & 1.5010 & +148.33 \\ \text { Bergium } & 260 & 0.456 & 1.015 & 1.4962 & +121.92 \\ \text { Italy } & 260 & 0.478 & 1.012 & 1.5000 & +157.50 \\ \text { Poland } & 260 & 0.425 & 1.008 & 1.4875 & +95.16 \\ \text { Portugal } & 260 & 0.400 & 0.993 & 1.4871 & +72.73\end{array}$

As shown in the above table, the oils of five strains except the French strain were highly dextro-rotatory and showed strong absorption at $260 \mathrm{~m} \mu$. The presence of rotundifolone was also proved by semicarbazone and iso-rotundifolone (diosphenolene) formation ${ }^{1)}$. These facts indicate that most of European Mentha rotundifolia are completely identical with those of Japan and America. But the French oil shows different aspects, which gave 2,4-dinitro-phenylhydrazone melting at $157^{\circ}$ as a red-orange crystal. The detailed properties of this oil will be reported in the near future.

\section{Sumio Shimizu}

Nagamori IKEDA*

Laboratory of Agricultural Chemistry,

Faculty of Agriculture, Shinshu University Received March 19, 1958

9) N. Ikeda and S. Udo, Scientific Reports of Faculty of Agric. 9kayama Univ., 4, 43. (1954).

* Laboratory of Plant Breeding, Faculty of Agric,. Okayama University. 